\title{
Assessment of Health Tourism Marketing in Turkey
}

\author{
DOI: $10.26466 /$ opus.899400
}

\author{
Cansu Patc1 ${ }^{*}$ - Ece Uğurluoğlu Aldoğan** \\ * Gr. St., Ankara University, Ankara /Turkey \\ E-Mail: cansuptc@gmail.com \\ ORCID: 0000-0003-4683-4935 \\ ** Assoc. Prof. PhD, Ankara University, Faculty of Health Sciences, Ankara/Turkey \\ E-Mail: ugurluoglu@health.ankara.edu.tr \\ ORCID: $\underline{0000-0001-9537-7027}$
}

\begin{abstract}
The aim of this study is to determine how the thermal hotels that provide services for thermal tourism apply and evaluate the marketing mix elements (product, price, place, promotion). After receiving the ethical approval for the research on 05.03.2018, a questionnaire has been applied to mid-level, senior level managers or team members of each Thermal Hotel that received the Tourism Operation License from the Ministry of Culture and Tourism in Turkey. A total of 71 survey forms were obtained from 77 apart thermal hotels and thermal hotels holding operating certificate. According to the results, $53.5 \%$ of the customers choose thermal hotels individually. $60.6 \%$ of customers prefer to rest in the hotel. The important marketing objectives for the managers were found as; to ensure the continuity of the enterprise and maximize customer satisfaction. Thermal hotels use personal sales and public relations most effectively as promotion tools. Thermal tourism is an important type of tourism in terms of contributing to the country's economy and increasing tourism diversity. At this point, the marketing activities applied by the organizations are of great importance in terms of ensuring the expected contribution of thermal tourism.
\end{abstract}

Keywords: Marketing, Health Tourism, Thermal Tourism. 


\section{Türkiye'de Sağlık Turizmi Pazarlamasının Değerlendirilmesi}

\section{Öz}

Bu çalışmanın amacı termal turizme yönelik hizmet veren termal otel işletmelerinin pazarlama karması elemanların (hizmet, fiyatlandırma, dağıtım, tutundurma) nasıl uyguladıkları ve değerlendirdikleri tespit etmektir. Araştırma için 05.03.2018 tarihinde etik kurul izni alındıktan sonra T.C. Kültür ve Turizm Bakanlı̆̆g'ndan turizm işletme belgesi almış termal otel ve termal müstakil apart otel olarak nitelendirilen işletmelerin pazarlama/satın alma birimlerinin üst-orta düzey ya da ekip elemanı olarak görev yapan birer kişiye anket formu uygulanmıştır. Toplam 77 termal müstakil apart otel ve termal otelden, 71 adet kullanılabilir anket formu elde edilmiştir. Araştırma sonucuna göre termal otel işletmelerine gelen müşterilerin \%53,5'i bireysel olarak gelmektedir. Müşterilerin \%60,6'sı işletmeyi dinlenme için tercih etmektedir. Yöneticiler için işletmenin devamlılığın sağlamak ve müşteri memnuniyetini en üst seviyeye çıkarmak en önemli pazarlama hedeflerindendir. Termal otel işletmeleri tutundurma araçlarından kişisel satış ve halkla ilişkileri en etkin şekilde kullandıkları görülmüştür. Termal turizm bir ülkenin ekonomisine ve turizm çeşitliliğine katkı sağlayan önemli bir alandır. Bu noktada termal turizme beklenen katkıyı sağlayabilmek adına ilgili kurumların pazarlama faaliyetleri önemli olacakttr.

Anahtar Kelimeler: Pazarlama, Sağllk Turizmi, Termal Turizm. 


\section{Introduction}

Marketing is about identifying and meeting human and social needs (Kotler and Keller, 2016, p.26). The American Marketing Association's (AMA) definitions of marketing and marketing research are reviewed and reapproved/modified every three-years by a panel of five scholars who are active researchers. AMA's 2017 approved marketing definition is "Creating, communicating, delivering, and exchanging offerings that have score for customers, clients, partners, and society at large" (AMA, 2017).

McCarthy (1964) has introduced the marketing mix elements known as $4 \mathrm{P}^{\prime}$ s of marketing; product, price, promotion, and place (McCarthy and Perreault, 1964). Booms and Bitner (1981) stated that the essential elements of product, place, price and promotion remain, but three additional variables people, and process and physical evidence are included producing a 7Ps mix (Booms and Bitner, 1981, p.47-51).

A product is defined as a bundle of attributes (features, functions, benefits, and uses) capable of exchange or use; usually a mix of tangible and intangible forms. Thus a product may be an idea, a physical entity (a good), or a service or any combination of the three. Products, such as a bank loan or home security, that are intangible or at least substantially so. If totally intangible, they are exchanged directly from producer to user, cannot be transported or stored, and are almost instantly perishable (Armstrong and Kotler, 2015, p.230).

Service products are often difficult to identify because they come into existence at the same time they are bought and consumed. They comprise intangible elements that are inseparable, they usually involve customer participation in some important way, they cannot be sold in the sense of ownership transfer, and they have no title. However, most products are partly tangible and partly intangible, and the dominant form is used to classify them as either goods or services (all are products). These common, hybrid forms, whatever they are called, may or may not have the attributes just given for totally intangible services. Other examples include travel services, entertainments events (e.g., movie theaters), and health care (AMA, 2020). 
Price is the formal ratio that indicates the quantity of money, goods or services needed to acquire a given quantity of goods or services and is the amount a customer must pay to acquire a product. Place refers to the act of marketing and carrying products to consumers. It is also used to describe the extent of market coverage for a given product. Distribution is represented by place or placement. According to the Association of National Advertisers (ANA), promotion marketing includes tactics that encourage short-term purchase, influence trail and quantity of purchase, and are very measurable in volume, share and profit (AMA, 2020).

Tourism is the movement of tourists from one place to another place. It is the temporary, short-term movement of people to destinations outside the place where they normally live and work. It includes the activities they indulge in at the destination as well as all facilities and services specially created to meet their needs. Tourism does not only mean traveling to a particular destination but also includes all activities undertaken during the stay. It includes day visits and excursions. The movement can be in ones own country or the tourists can also travel to the foreign destinations for the tourism purpose (Arunmazhi and Panneerselvam, 2013, p.84-88).

The types of tourism are dynamic in time, they vary a lot. The types of tourism presented in a given period are generated by the needs of its objectives, the level of cultural and social facilities and the existing means of transport. In general, one may distinguish six types of tourism: relaxing tourism; relaxing and health care tourism; visiting tourism; transit tourism; reduced distance tourism; professional tourism (Cornalia and Turtureanu, 2008, p.92-103).

Some of the earliest forms of tourism were directly aimed at increased health and well being: for example, the numerous spas that remain in many parts of Europe and elsewhere, which in some cases represented the effective start of local tourism, when 'taking the waters' became common by the 18th century (Connell, 2006, p.1093-1100).

Republic of Turkey Ministry of Culture and Tourism has defined health tourism as "Traveling to a foreign country to get preventive, curative and/or rehabilitative health care" (Republic of Turkey Ministry Culture and Tourism, 2018). 
The types of Health Tourism have been classified as; Senior Tourism and Accessible Tourism, Thermal Health Tourism and SPA-Wellness and Medical Tourism. Spa treatments and physiotherapies, thalassotherapies, hydrotherapy and exercises, balneotherapy and peloidotherapy, and climatotherapy are provided under the thermal health tourism and SPA-Wellness (Republic of Turkey Ministry of Health Tourism Department, 2020).

Health tourism is a broad concept that encompasses both wellness tourism and medical tourism. Medical, or health, tourism is one of the fastest-growing tourism sectors internationally, and many countries are currently planning legally and practically for this market. Medical tourism refers to a vacation that involves traveling across international borders to obtain a broad range of medical services. It usually includes leisure, fun, and relaxation activities, as well as wellness and health-care service (Heung, Küçükusta and Song, 2010, p.236-251). The development of this sector within the tourism industry has led to the emergence of new niche markets, with different destinations. In order for organizations that provide services for health tourism such as thermal hotels need to, determine their marketing mix strategies according to the needs of the customers and expectations. Gonzales, Brenzel and Sancho, 2001).

Thermal tourism is an important type of tourism in terms of contributing to the country's economy and increasing tourism diversity. The aim of this study is to determine how the thermal hotels that provide services for thermal tourism apply and evaluate the marketing mix elements (product, price, place, promotion). At this point, the marketing activities applied by the organizations are of great importance in terms of ensuring the expected contribution of thermal tourism.

\section{Methods}

This is a descriptive study to determine how the elements of marketing mix are developed and applied in thermal tourism organizations. After receiving the ethical approval on 05.03.2018 for the study, a questionnaire has been applied to employees working as the top-medium level or the team members in marketing departments of the thermal hotels and the thermal apart hotels licensed from Republic of Turkey Ministry of 
Culture and Tourism. In the study; out of 77 hotels licensed thermal hotels and apart thermal hotels 71 thermal hotels could be reached. The research covers the 3-4 and 5 star thermal hotels and thermal apart hotels in Turkey.

İlker's (2012) questionnaire has been used to collect data to determine the marketing strategies of thermal hotels in Turkey. There are total of 27 questions and 6 sections in the questionnaire. The items in the first section are related with the thermal hotels in general. The second section consists 11 items to determine the importance of the marketing targets. While 6 items in the third section are related with the services in thermal hotels, 2 items are pricing strategies related in the fourth section. The fifth section has 3 items that are related with the distribution strategies of the services and the last section has items related with the promotion element of marketing mix. Cronbach's Alfa Coefficient has been measured as 0,92 . Scores of the scale are evaluated as 1 "not important" and 5 "very important". Total of 75, 3-4 star and 5 star thermal hotels and 2 thermal apart hotels were contacted via e-mail and additionally frequent telephone calls were made to expedite the replies. The purpose of questionnaire has been explained to the marketing-sales departments or the authorized personnel of the hotels via e-mail messages and the telephone calls. After these contacts, questionnaires have been forwarded to the email accounts addressed by the authorized persons together with the detailed explanations. Data was analyzed by SPSS 23.0 version. One-way ANOVA was conducted to evaluate data. Tukey HSD and Tamhane's T2 tests have been conducted to determine homogeneity. Result of analysis were presented as mean and the standard deviation and the level of significance were taken as $\mathrm{p}<0,05$.

\section{Findings}

\section{The Locations of the Thermal Hotels}

The information related to the locations of the thermal hotels included in the research are provided in Table1. The most number of thermal hotels is located in Afyon. 
Table 1. Locations of thermal hotels

\begin{tabular}{lll}
\hline Location & $\mathbf{n}$ & \% \\
\hline Afyon & 9 & 12,7 \\
Ankara & 7 & 9,9 \\
Bursa & 7 & 9,9 \\
Denizli & 7 & 9,9 \\
İzmir & 7 & 9,9 \\
Balıkesir & 6 & 8,5 \\
Yalova & 5 & 7,0 \\
Amasya & 3 & 4,2 \\
Kütahya & 3 & 4,2 \\
Nevşehir & 3 & 4,2 \\
Diğer (Antakya, Batman, Bolu, Çanakkale, Çankırı, Eskişehir, & 14 & 19,6 \\
Kahramanmaraş, Kırşehir, Kocaeli, Manisa, Niğde, Samsun, Tunceli, Yozgat) & 71 & 100,0 \\
Total & \multicolumn{2}{c}{}
\end{tabular}

\section{Star Rates of Thermal Hotels}

It is seen in Table 2 that $50,7 \%$ of the thermal hotels are 5 star-rated, while the $26,8 \%$ are 4 star-rated and $22,5 \%$ are 3 star-rated.

Table 2. Star rates of thermal hotels

\begin{tabular}{lll}
\hline & $\mathbf{n}$ & $\mathbf{\%}$ \\
\hline 5 Star-rated & 36 & 50,7 \\
4 Star-rated & 19 & 26,8 \\
3 Star-rated & 16 & 22,5 \\
Total & 71 & 100,0 \\
\hline
\end{tabular}

\section{Number of Employees in Thermal Hotels}

It has been determined that there are 30 to 60 employees working in 21 thermal hotels while the number of employees of 7 thermal hotels are between 121 to 140 (Table 3).

Table 3. Number of employees in thermal hotels

\begin{tabular}{lll}
\hline & $\mathbf{n}$ & $\mathbf{\%}$ \\
\hline $30-60$ & 21 & 29,6 \\
$61-80$ & 9 & 12,7 \\
$81-100$ & 8 & 11,3 \\
$101-120$ & 12 & 16,9 \\
$121-140$ & 7 & 9,8 \\
More than 141 & 14 & 19,7 \\
Total & 71 & 100,0 \\
\hline
\end{tabular}




\section{The Preference of the Customers}

As seen in the Table 4,53,5\% of the customers choose the thermal hotels individually, while $32,4 \%$ prefer to choose the hotels through agencies, $11,3 \%$ choose as a group and $2,8 \%$ prefer to choose the thermal hotels through the social security contracts (Table 4 ).

Table 4. The preference of the customers

\begin{tabular}{lll}
\hline & $\mathbf{n}$ & $\mathbf{\%}$ \\
\hline Individual & 38 & 53,5 \\
Agency & 23 & 32,4 \\
Group & 8 & 11,3 \\
Social Security & 2 & 2,8 \\
Total & 71 & 100,0 \\
\hline
\end{tabular}

\section{Reasons of Staying in a Thermal Hotel}

It is fund that the majority $(60,6 \%)$ of the customers go to the thermal hotels to rest, while $23,9 \%$ to get health services and treatment, $8,5 \%$ to have business-meetings and $7 \%$ to have entertainment (Table 5).

Table 5. Reasons of staying in a thermal hotel

\begin{tabular}{lll}
\hline & $\mathrm{n}$ & $\%$ \\
\hline Resting & 43 & 60,6 \\
Health-Treatment & 17 & 23,9 \\
Business-Meeting & 6 & 8,5 \\
Entertainment & 5 & 7,0 \\
Total & 71 & 100,0 \\
\hline
\end{tabular}

Findings Related with Marketing Purposes: It is seen in Table 6 that the most important marketing purposes of the thermal hotels are determined as "Sustainability of organization" and "keeping of the customer satisfaction at highest level" 
Table 6. The Importance of Marketing Purposes

\begin{tabular}{lll}
\hline Marketing Purposes & mean $^{*}$ & st. deviation \\
\hline Keeping the Sustainability of Organization & 4,90 & 0,30 \\
Increasing the Customer Satisfaction to Highest Level & 4,83 & 0,37 \\
Increasing the Sales & 4,55 & 0,50 \\
Keeping the Profitability at Highest Level & 4,56 & 0,49 \\
Saving and Increasing the Market Share & 4,51 & 0,58 \\
Paying the Costs and Having Profit & 4,51 & 0,58 \\
Improving the Image of Organization & 4,62 & 0,48 \\
Providing a Competitive Advantage & 4,48 & 0,58 \\
Achieving the Targeted Level of Profit & 4,51 & 0,53 \\
Being Useful to Society & 4,46 & 0,55 \\
Increasing the Wealth Level of Employees and their Families & 4,35 & 0,56 \\
\hline
\end{tabular}

*1=not important, 5=very important in the scale.

Findings related with Services Provided: Information regarding the services provided for thermal and/or treatment purposes by the thermal hotels is shown in Table 7.

Table 7. Thermal and/or treatment services provided in thermal hotels *

\begin{tabular}{lll}
\hline & $\mathrm{n}$ & $\%$ \\
\hline Indoor Swimming Pool & 68 & 95.8 \\
Turkish Bath & 65 & 91.5 \\
Other (Steam and Salt Room) & 2 & 2.82 \\
Massage & 55 & 77.5 \\
Sauna & 54 & 76.1 \\
Fitness Center & 46 & 64.8 \\
Outdoor Swimming Pool & 47 & 66.2 \\
Kids Pool & 45 & 63.4 \\
Thermal Pool with Jacuzzi & 42 & 59.2 \\
Jacuzzi Pool & 36 & 50.7 \\
Private Family Bath & 36 & 50.7 \\
Hiking trails & 35 & 49.3 \\
Aromatherapy & 21 & 29.6 \\
Mud Bath & 17 & 23.9 \\
Shock Pool & 18 & 25.4 \\
Physical Treatment & 15 & 21.1 \\
Herbal Bath & 9 & 12.7 \\
Solarium & 4 & 5.6 \\
X-ray and Cardiography & 3 & 4.2 \\
Milk bath & 1 & 1.4 \\
\hline
\end{tabular}

*More than one service could be selected 
It is seen that there are indoor pools, Turkish baths, saunas, massage units and services in the majority of the organizations included in the study. Again, it is seen that $66.2 \%$ of the thermal hotels have outdoor swimming pools, $64.8 \%$ have Fitness Centers, $63.4 \%$ have pool for kids, $59.2 \%$ have thermal pool with jacuzzi, 50.7\% have jacuzzi pool and private family bath, $49.3 \%$ have hiking trails, $29.6 \%$ have aromatherapy, $25.4 \%$ have shock pools, 23.9 have mud baths, $21.1 \%$ have physical treatment units, $12.7 \%$ have herbal baths, $5.6 \%$ have solarium units, $4.2 \%$ have X-ray and cardiography services, $2.8 \%$ have steam and salt rooms (other) and $1.4 \%$ have milk bath services.

\section{The Ways Thermal Hotels Determine which Services to Provide}

The ways the thermal hotels determine which services they will provide are seen in Table 8 . They provide their services mostly according to the claims of their guests $(97.2 \%)$ and conducted market surveys $(78.9 \%)$. $60.6 \%$ of the thermal hotels have stated that they rely on their past experiences and $53.5 \%$ consulted the recommendations of experts.

Table 8. The ways thermal hotels determine which services to provide

\begin{tabular}{lll}
\hline & $\mathrm{n}$ & $\%$ \\
\hline Evaluating Guest's Requests & 69 & 97.2 \\
Conducting Market Surveys & 56 & 78.9 \\
Relying on Our Experiences & 43 & 60.6 \\
Consulting to Recommendations of Experts & 38 & 53.5 \\
Review of Articles of Law & 23 & 32.4 \\
Taking Practices of competitors as an Example & 23 & 32.4 \\
\hline
\end{tabular}

${ }^{*}$ More than one service could be selected

\section{The Methods of How to Improve the Services Provided in Thermal Hotels}

Information on how the services provided are improved at the thermal hotels are presented in Table 9. It is seen that $91.5 \%$ of the hotels consider the guest's requests in the improvement of the services they provide. While marketing research is the second most relied method preferred, $60.6 \%$ of the participants also considered following the new trends in the 
improvement of the services. The first issue taken into consideration by most of the thermal hotels included in the study was the option of evaluating the requests of the customers indicates that thermal hotels are giving great significance to customer satisfaction.

Table 9. Methods of how to improve the services provided in thermal hotels

\begin{tabular}{lll}
\hline & n & \% \\
\hline Evaluating guest's requests & 65 & 91.5 \\
Following new trends & 43 & 60.6 \\
Marketing research & 44 & 62 \\
Personnel training & 37 & 52.1 \\
Relying on experiences & 35 & 49.3 \\
Consulting to Recommendations of Experts & 33 & 46.5 \\
Taking Practices of Competitors as a Sample & 16 & 22.5 \\
No improvement efforts & 4 & 5.6 \\
\hline
\end{tabular}

*More than one option could be selected

\section{Departments Providing In-Service Trainings}

While $92.9 \%$ of the thermal hotels included in the study provide inservice training to their employees, in-service training is given by both the department supervisors and the sales/marketing departments in $59.1 \%$ of the thermal hotels included in the study. It is seen that in $27.3 \%$ of the thermal hotels in service training is given by human resources departments and $45.5 \%$ is given by experts (Table 10 ).

Table 10. Departments giving in-service training in thermal hotels

\begin{tabular}{lll}
\hline & $\mathbf{n}$ & $\mathbf{\%}$ \\
\hline Department Supervisor & 39 & 59.1 \\
Sales/Marketing Department & 39 & 59.1 \\
Experts & 30 & 45.5 \\
Human Resources Department & 18 & 27.3 \\
\hline
\end{tabular}

${ }^{*}$ More than one option could be selected

\section{Findings Related with Pricing}

Information on the importance of the factors taken into consideration in pricing the services provided in the thermal hotels that participated in 
the study is presented in Table 11. The most important factors are "Service quality" and "hotel image" for the thermal hotels in setting prices.

Table 11. Importance of the Factors in Pricing

\begin{tabular}{lll}
\hline & mean & Standard Deviation \\
\hline Hotel Image & 4.55 & 0.53 \\
Sensitivity of the Guests towards Price & 4.34 & 0.63 \\
Targeted Sales Level & 4.39 & 0.52 \\
Competition Density & 4.08 & 0.67 \\
Cost of Service & 4.41 & 0.52 \\
Service Quality & 4.55 & 0.56 \\
Service Diversity & 4.23 & 0.57 \\
Targeted Profit Amount & 4.25 & 0.69 \\
Commission Rates Paid to Mediators & 3.68 & 0.81 \\
Legal Arrangements & 3.93 & 0.90 \\
Current Economic Situation & 4.28 & 0.64 \\
Campaign and Sales Policies & 4.28 & 0.64 \\
\hline
\end{tabular}

\section{Findings related with Promotion Activities}

It is seen in Table 12 that all organizations that participated in the study conducts promotion activities for their existing customers. Again, 81.7\% of the hotels conduct promotion towards potential customers while $60.6 \%$ prefer to conduct promotional activities for operators and $52.1 \%$ for travel agencies.

Table 12. Target market of the promotion activities of the thermal hotels

\begin{tabular}{lll}
\hline & Quantity & $\%$ \\
\hline Existing Customers & 71 & 100.0 \\
Potential Customers & 58 & 81.7 \\
Tour Operators & 43 & 60.6 \\
Official Departments & 34 & 47.9 \\
Travel Agencies & 37 & 52.1 \\
Persons Deciding on Behalf of the Customer & 37 & 52.1 \\
Trade and Industry Organizations & 29 & 40.8 \\
Accommodation Organizations & 30 & 42.3 \\
Sports Clubs & 27 & 38.0 \\
Food \& Beverages Organizations & 25 & 32.5 \\
Non-Profit Organizations & 21 & 29.6 \\
Shopping Organizations & 18 & 25.4 \\
Airway Companies & 12 & 16.9 \\
\hline
\end{tabular}

*More than one option could be selected 


\section{Departments Conducting the Promotion Activities in the Organiza- tions}

According to the results, the promotion activities of the thermal hotels are mostly carried out by the hotel personnel (77.5\%), 39.4\% of the thermal hotels promote their services with a marketing company and $26.8 \%$ of them by a marketing consultancy company (Table 13).

Table 13. Persons conducting the promotion activities in the organizations participating in the study

\begin{tabular}{lll}
\hline & Quantity & \% \\
\hline Hotel personnel & 55 & 77.5 \\
Jointly with a marketing consultancy company & 28 & 39.4 \\
By a marketing consultancy company & 19 & 26.8 \\
Jointly with an advertisement agency & 10 & 14.1 \\
Other (Board of Directors) & 1 & 1.4 \\
\hline
\end{tabular}

*More than one option could be selected

\section{Effectiveness of Promotion Tools}

It is seen in Table 14 that "direct marketing" is the promotion tool with the highest effectiveness level in thermal hotels. This is followed by public relations and publicity, personal sales, advertisement and sales development respectively. It can be concluded from this output that direct marketing activities through methods such as direct sales, catalog, telephone, television and internet sales and marketing is considered as the method with the highest effectiveness by the organizations.

Table 14. Effectiveness of promotion tools in organizations included in the study

\begin{tabular}{lll}
\hline & mean & Standard Deviation \\
\hline Advertisement & 3.99 & 0.78 \\
Personal Sales & 4.07 & 0.96 \\
Public Relations and Publicity & 4.07 & 0.87 \\
Promotion & 3.97 & 0.77 \\
Direct Marketing & 4.23 & 0.79 \\
\hline
\end{tabular}

Findings Related with Distribution: In terms of working with a travel agency, the thermal hotels mostly pay attention to the reliability of the travel agencies (Table 15). 
Table 15. The important factors in working with a travel agency

\begin{tabular}{lll}
\hline & mean & Standard Deviation \\
\hline Reliability & 4,70 & 0,49 \\
Customers they can provide & 4,51 & 0,74 \\
Quality of their services & 4,48 & 0,81 \\
Market capacities & 4,48 & 0,74 \\
Economic potential & 3,51 & 1,24 \\
Location & 3,75 & 0,97 \\
Popularity & 3,28 & 1,29 \\
\hline
\end{tabular}

*1=not important, $5=$ very important in the scale.

\section{Discussion and Recommendations}

In order for thermal hotels to stay in the thermal tourism market, they need to establish marketing mix elements (service (product), price, distribution and promotion) that are in compliance with the requests and expectation of the consumers for them to compete and operate efficiently.

While there are different studies focusing on different parts of thermal tourism (Ilker, 2012; Avcıkurt, Giritlioğlu and Şahin, 2011; Çiçek and Avderen, 2013; Yalçınkaya, 2014; Kotan, 2018) this study was carried out with 71 thermal hotels in 24 different cities as it covered thermal hotels with operation license throughout Turkey.

The most important target aimed to be achieved with the marketing activities was found to be "keeping the sustainability of the organization" and "increasing the customer satisfaction to highest level" both in this study and study of Ilker (2012). While the reasons of customers for staying in a thermal hotel are $23.9 \%$ for health/treatment and $60.6 \%$ for resting in this study, these percentages were $76.6 \%$ for health/treatment and $23.4 \%$ for resting in Çiçek and Avderen's (2013) study, $36.10 \%$ for health/treatment and $33.30 \%$ for recreation in Ilker's (2012) study, and $28.1 \%$ for health/treatment and $45.7 \%$ for recreation in Yalçınkaya's (2014) study.

It must be ensured that customers come to the thermal hotels mostly for health and treatment, and it can recommended that inefficiencies related with health and treatment units must be fulfilled in compliance of the consumer requests. Qualified doctors, nurses and health personnel may be employed to ensure that the customers come to the organizations 
for health and treatment. Moreover, the organizations may design their physical conditions according to the guests. It is considered that necessary courses could be planned to train personnel with required qualifications so that the thermal accommodation organizations achieve the standards for serving the international market. It can also be recommended that greater importance should be given to promotion activities for the thermal hotels to acquire a share from the foreign tourist market. It is considered that it will be useful if the thermal hotel organizations conducted more market research, obtain recommendations from related experts, follow the new trends and organize training aiming at the personnel when determining the services to be provided at the thermal hotels.

It can be recommended that arrangements and innovations can made physical structure and service quality. Certification of the thermal organizations according the international quality standards may be recommended. Thermal hotel organizations may be directed towards the clustering approach in terms of competitive power strategies.

It may be recommended that the thermal hotel organizations make agreements with social security organizations. Thermal hotel organizations may turn towards internet sales to adapt to the digital world and to ensure continuity of the organizations. It is believed that thermal hotel organizations may reach a greater market share by using the social media more effectively.

Activity environments can be created and various activity events may be organized to ensure that the guests coming to the thermal hotel organizations for treatment and/or recreation make more effective use of their leisure time.

It may also be suggested to the thermal hotels that they need to make more effective use of promotion tools to increase their sales and fulfill the hotel preferences of the customers. Marketing mix evaluation may be recommended for future studies for all thermal hotel organizations that do or do not have thermal hotel operation license. 


\section{References}

American Marketing Association (2017). Accessed on 4th October 2018 from https://www.ama.org/the-definition-of-marketing-what-is-marketing/

American Marketing Association (2017). Accessed on 14th November 2018 from https://marketing-dictionary.org/s/services/ Price

Armstrong, G. and Kotler, P. (2015). Products, services and brands building customer score. Marketing an introduction. 20 thed. England. Pearson Education Limited.

Arunmazhi, T and Panneerselvam A. (2013). Types of tourism in India. International Journal of Current Research and Academiz Rewiev, 1(1), 84-88.

Avcıkurt, C., Giritlioğlu, İ. and Şahin, S. (2011). An evaluation of thermal hotel websites and the use/non-use of the internet as a marketing tool by thermal hotels in Turkey. African Journal of Business Management, 5, 2817-2827.

Booms, B. H. and Bitner, M. J. (1981). Marketing strategies and organization structures for service firms. In: Donnely JH, George WR, eds. Marketing of Services.1 th ed. Chicago: American Marketing Association.

Connell, C. (2006). Medical tourism: Sea, sun, sand and surgery. Tourism Management, 27, 1093-1100.

Cornalia, E. T. and Turtureanu, A. (2008). Types and forms of tourism. Acta Universitatis Danubius, Economia, 4(1), 92-103.

Çiçek, R. and Avderen, S. (2013). Healthy tourism and spa and thermal facilities in central anatolia: A research on determining the current structure and potentials. Karamanoğlu Mehmetbey Üniversitesi Sosyal ve Ekonomik Araştırmalar Dergisi, 15, 25-35.

Gonzales A, Brenzel L and Sancho J. (2001). Health tourism and related services: caribbean development and international trade. Final report.

Heung, V. C. S., Küçükusta, D. and Song, H. (2010). A conceptual model of medical tourism: Implications for future research. Journal of Travel $\mathcal{E}$ Tourism Marketing, 27, 236-251.

Ilker, G. (2012). The marketing mix elements in accomodation enterprises serving termal tourism in Turkey: A sample field study. (Doctoral thesis). Selçuk University, Institute of Social Sciences, Department of Business Administration, Konya.

Kotan, N. (2018). Destination marketing and thermal tourism as an alternative tourist product: The case of Erzurum. (Master thesis). Erciyes University, Institute of Social Sciences, Department of Tourism Management, Kayseri.

Kotler, P. and Keller, K. L. (2016). Introduction to marketing management. A framework for marketing. 6th ed. England. Pearson Education Limited. 
Perreault, W.D. and McCarthy, E. J. (1964). Basic marketing: A managerial approach. The United States, Mc Graw-Hill.

Republic of Turkey Ministry Culture and Tourism (2018). Accessed of 18th September 2018 from http://yigm.kulturturizm.gov.tr/TR,11475/genel-tanimlar.html

Republic of Turkey Ministry of Health Tourism Department (2020). Accessed of 26th February 2020 from https:/saglikturizmi.saglik.gov.trl

Yalçınkaya, Z. (2014). A research for role of City Trademark Image in Thermal Tourism Marketing and Instance of Kütahya. (Master thesis). Dumlupınar University, Institute of Social Sciences, Department of Business Administration, Kütahya.

\section{Citation Information}

Patcı, C. and Uğurluoğlu Aldoğan, E. (2021). Assessment of health tourism marketing in Turkey. OPUS-International Journal of Society Research, 18(41), 3082-3098. DOI: 10.26466/opus.899400. 